TITLE:

\title{
CONTRIBUTIONS TO JAPANESE ASCIDIAN FAUNA XXII. -ASCIDIANS FROM SADO ISLAND (2)-
}

AUTHOR(S):

Tokioka, Takasi

\section{CITATION:}

Tokioka, Takasi. CONTRIBUTIONS TO JAPANESE ASCIDIAN FAUNA XXII. -ASCIDIANS FROM SADO ISLAND (2)-. PUBLICATIONS OF THE SETO MARINE BIOLOGICAL LABORATORY 1967, 15(3): 239-244

ISSUE DATE:

1967-10-30

URL:

http://hdl.handle.net/2433/175465

RIGHT: 


\title{
CONTRIBUTIONS TO JAPANESE ASCIDIAN FAUNA XXII. ASCIDIANS FROM SADO ISLAND (2) ${ }^{1)}$
}

\author{
TAKASI TOKIOKA
}

Seto Marine Biological Laboratory

With 1 Text-figure

Nineteen ascidians collected along the exposed coast of Sado Island in the Japan Sea were already referred to in my previous paper (Contributions to Japanese ascidian fauna XVIII, Publ. Seto Mar. Biol. Lab., X (1), 1962, pp. 1-20, 3 pls.). In April 1966, eleven more ascidians were collected in Lake Kamo by Dr. T. KiтAmi of the Sado Marine Biological Laboratory of Niigata University. The lake is a lagoon situated on the northeast coast of the island and famous as an oyster farm in the island. Therefore this small ascidian collection may be regarded as a representative of the materials from the protected water of the island. The species included are:

* 1. Didemnum (Didemnum) moseleyi (Herdman)

2. Leptoclinum mitsukurï (Ока)

* 3. Distaplia dubia (Ока)

* 4. Distaplia sp. aff. dubia (OkA)

5. Ciona intestinalis (Linnaeus)

* 6. Perophora japonica Oka

* 7. Ascidia zara Oka

* 8. Botryllus schlosseri (PaLlas)

9. Botrylloides violaceus OKa

10. Styela partita (Stimpson)

*11. Styela clava Herdman.

Seven species marked with asterisk were not contained in the former collection from the exposed water. Thus, the total number of the ascidians known from Sado Island has increased to 26. Some notes for future discussions are given to certain species, especially to a form affined to Distaplia dubia (OKA), which shows some differences in the appearance of the system of zooids and also in the exact appearance of the thoracic musculature.

(1) Didemnum (Didemnum) moseleyi (Herdman) Five white colonies up to 17

1) Contributions from the Seto Marine Biological Laboratory, No. 472.

Publ. Seto Mar. Biol. Lab., XV (3), 239-244, 1967. (Article 13) 
$\mathrm{mm} \times 95 \mathrm{~mm}$ in extent. They are usually $1-2 \mathrm{~mm}$ thick, but may be $5 \mathrm{~mm}$ at the places where the colony is folded. Two colonies are still whitish, while other three colonies are pale orange or salmon pink in the preserved state. Zooids are indistinctly divided into a number of small, 1-2 mm long groups or a little larger 4-8 mm long groups in some parts of or over the whole colony. The retractile muscle is conspicuous, may be as long as the contracted thorax. Testicular follicle always single, the proximal part of the vas deferens coils about 6 times. The test is tough. Spicules of moseleytype, diameter of spicules $28 \mu$ on an average, $38 \mu$ at the maximum; 8-10 rays on the equatorial plane. In a $42 \mathrm{~mm} \times 14 \mathrm{~mm}$ and $1-1.5 \mathrm{~mm}$ thick colony, the spicules are found in a moderate density only in the surface layer and in the marginal area of the colony, but very sparsely in other parts; the superficial spiculeless layer is practically indiscernible. In this colony, the granular cells are very elongate in the surface layer of the central portion, $53 \mu$ long $\times 6 \mu$ wide for instance.

Two vermilion colonies, respectively $7 \mathrm{~mm} \times 8 \mathrm{~mm}$ and $10 \mathrm{~mm} \times 18 \mathrm{~mm}$ in extent and $3 \mathrm{~mm}$ in thickness in a folded state. They are pale orange brown as a whole in the preserved state, although the test itself is milky white, transparent, and tough. Most parts of the colonies are free from spicules; spicules are limited to a small part of the colony. Then at least the brownish colouration of the preserved specimens is due to the mantle pigment of the zooids which may be grouped into $1-2 \mathrm{~mm}$ long small areas in some parts of the colony. The structure of the zooid is quite the same as that of the white colonies. Spicules are apparently in a course of disintegration and found mostly in a state of the bundle of needles. A few spicules found perfect are of the moseleyi-type, $27 \mu$ in diameter on an average, $35 \mu$ at the maximum, and with 6-7 rays on the equatorial plane. Granular cells of the test are very dense and round to elliptical in shape; those from the marginal area are about $26 \mu$ long $\times 12 \mu$ wide and include $40-50$ granules within. Most probably, these are the coloured specimens of $D$. (D.) moseleyi. However, it is uncertain whether the vermilion colouration of the live colonies was caused by the mantle pigment of zooids or by the pigment cells in the test tissue, which are completely faded in the preservative.

(2) Leptoclinum mitsukurii (OKA) The colonies were pale bluish black when alive. Zooids are immature.

(3) Distaplia dubia (Ока) A $30 \mathrm{~mm} \times 10 \mathrm{~mm}$ in extent and $2.5 \mathrm{~mm}$ thick encrusting colony and a $12 \mathrm{~mm}$ long cylindrical colony with a $3.5 \mathrm{~mm}$ diameter, both coloured pale bluish gray in formalin.

(4) Distaplia sp. aff. dubia (OKA) Seven vermilion colonies, two brownish colonies, one pinkish and two whitish colonies in the material. In formalin, the colonies are faded mostly to grayish yellow, but some are grayish white or yellowish white. The test looks translucent and milky white, and generally grayish or whitish to yellowish brown zooids are seen through, and then the colony surface may be seen reticulated with grayish meshes as the zooids are gathered in systems. The larger colonies 
attain $40 \mathrm{~mm} \times 50 \mathrm{~mm}$ or $35 \mathrm{~mm} \times 60 \mathrm{~mm}$ in extent. Smaller colonies are usually 1-2 $\mathrm{mm}$ in thickness. In larger colonies, however, the colony surface which is generally smooth may be raised at places to form irregular lobes, there the colony becomes as thick as $10 \mathrm{~mm}$ or more. Systems of zooids are very complicated as seen in Figs. $a$ and b, each consisting of much more zooids than in D. dubia; larger systems are $8-10 \mathrm{~mm}$ in length. Small systems containing 8 zooids or thereabout may be found partly, but they are extremely rare. The underside of the colony is penetrated with woven fascicular vessels. The colony margin contains vessels and ampullae as in botryllids. Some colonies are immature, but others are quite matured with many larvae in the surface layer of the colony.

Zooid: The dorso-ventral breadth of the contracted thoraces measured on the colony surface is about $1 \mathrm{~mm}$. In a considerably extended state, the thorax is $1.7-$ $2.0 \mathrm{~mm}$ long. The atrial aperture is very wide, the atrial languet of a moderate length; the tip is mostly simple, but may be bifid (Fig. c) or provided with a number of dents up to 4 (Fig. d), probably in zooids situated near the common cloacal aperture. The branchial aperture 6-lobed. Thoracic musculature may be divided provisionally into the following two types:

I-type-There are about 15 longitudinal muscles at the anterior level of the branchial sac, the dorsal half of them immediately join the atrial sphinctors and only the ventral half of them run posteriorly and obliquely toward the dorsal side at the posterior level of the branchial sac. Therefore only about seven longitudinal muscles are found at the middle level of the sac, and the ventro-posterior portion of the thorax is irregularly reticulated with thinner muscles (Fig. e).

II-type-Longitudinal muscles are fewer than in I-type, only 4-5 at the middle level. In place, the longitudinal muscles issue many branches at the anterior level so that the branchial siphon is supported by longitudinal muscle fibres as many as in I-type. The ventro-posterior reticulated area is much more prominent (Figs. $f_{1}, f_{2}$ ).

Some thorax may be furnished on one side with I-type musculature, while with II-type musculature on the other side. Fig. $g$ shows an unusual musculature found on the right side of a thorax, which is furnished with I-type musculature on the left side. Fifteen to 17 elongate stigmata in respective rows, one or two ventral stigmata are smaller than others; parastigmatic vessels distinct. The posterior margin of the last stigmatal row is nearly straight. Exact number of branchial tentacles are unknown because of strong contraction at that portion, about 8? The bilobed anus is attached to the branchial sac at the level of the third transverse vessel, though it is protruded more anteriorly.

The whole intestinal loop, from the anterior end of the oesophagus to the posterior end of the loop, is nearly as long as the extended thorax excluding the branchial siphon. The oesophagus is thicker posteriorly and well ridged. About two dozen irregular inner longitudinal plications are seen through the stomach wall. Midintestinal portion is constricted off very clearly from the proximal portion of the 


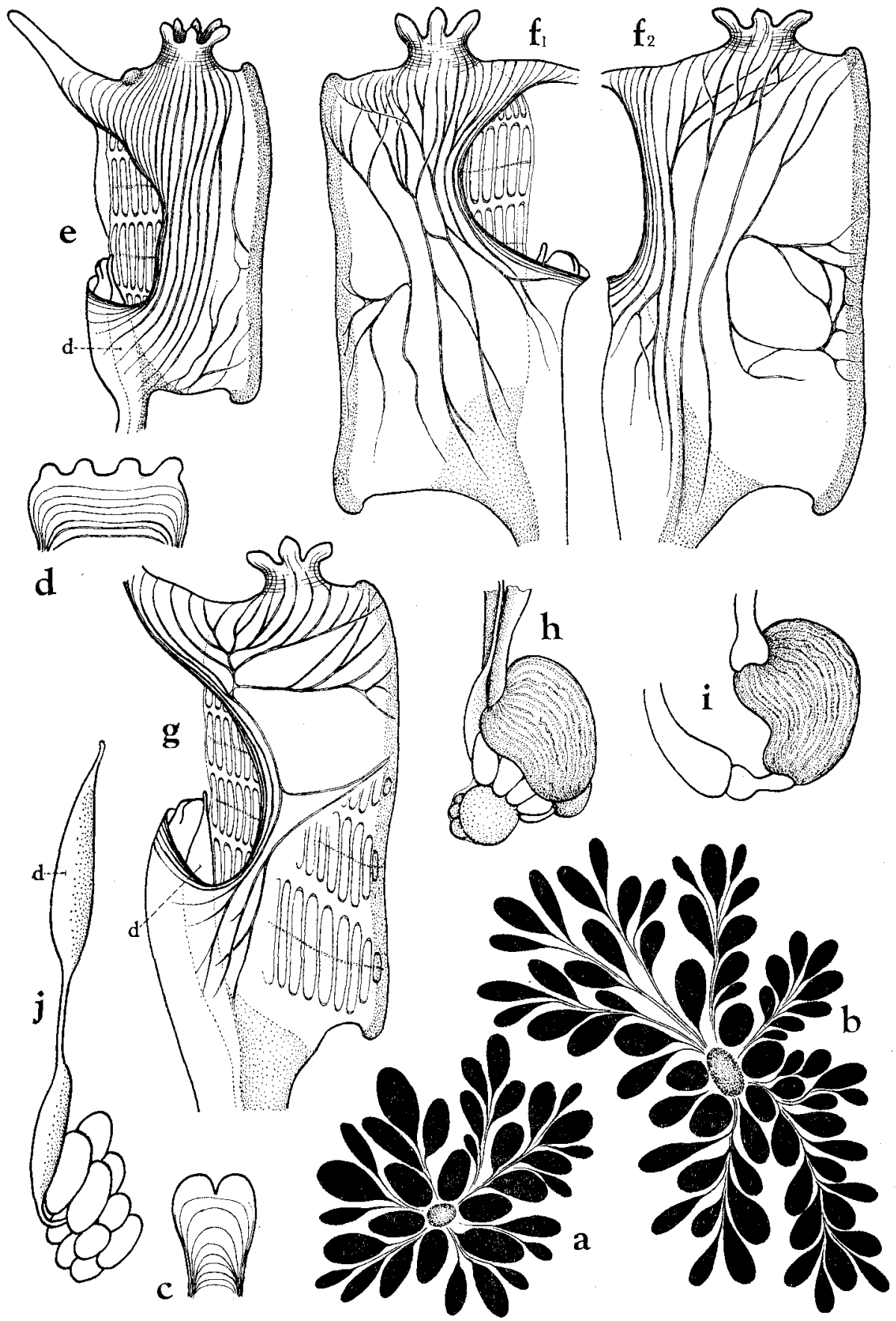

Fig. 1. Distaplia sp. aff. dubia (ОкА) a-7.5 mm long system, b- $10 \mathrm{~mm}$ long system, c-bifid atrial languet, $\mathrm{d}$-tip of atrial languet with 4 dents, e-thoracic musculature Type I (right side), $f_{1}-$ thoracic musculature Type II (left side), $f_{2}$-thoracic musculature Type II (right side), g-unusual thoracic musculature (right side), $\mathrm{h}$-abdomen (right side), $\mathrm{i}$-intestinal loop, $\mathrm{j}$-gonad. $d$-thickened distal part of vas deferens. 
rectum (Fig. i). The gonad occupies the left side of the intestinal loop. The ovary central, testicular follicles are 10-18, most frequently 12. The vas deferens runs up along the right side of the rectum and markedly swollen near the distal end (Fig. $\mathbf{j}$ d). Incubatory pouches are generally found detached. Larvae are 1140-1270 $\mu$ long in measured specimens. The larval test is frothy. The whole structure resembles closely that of $D$. dubia.

Remarks: The systems of zooids are much more complicated in the present specimens than in typical D. dubia. But, this might be attributable to the state of the asexual increasing of zooids. The thoracic musculature of II-type is rather unique, but it can be related to that of $D$. dubia through the I-type musculature. For these reasons, the specimens are treated as a form affined to $D$. dubia.

(5) Ciona intestinalis (LinNaEus) Eleven specimens, all with soft test and without any formation of peduncular portion. The anterior portion of the body is coloured with reddish orange spots and patches.

(6) Perophora japonica OKA Pale greenish and transparent when alive. Fully matured.

(7) Ascidia zara OKA Eight specimens, $22-40 \mathrm{~mm}$ in length. The anterior end of the intestinal loop reaches or approaches to the middle of the distance between the bases of branchial and atrial siphons. The axis of the second intestinal loop passes through the pyloric end of the stomach. The stomach is spherical and with longitudinal plications. Fully matured.

(8) Botryllus schlosseri (PALlas) Three colonies. Stellate systems consist of 6-14 zooids (most frequently 7-8). The test is colourless and transparent, zooids are about $1.5 \mathrm{~mm}$ long and purplish brown or pale olive to greenish gray on the anterior side of the thorax. Six to 9 stigmatal rows, usually one more row on the left side. Eight to 10 plications, including typhlosole, on the stomach. One to 2 ova on the dorsal side of the testis on the left and at the antero-dorsal corner of the testis on the right side, testicular follicles 2-4. Colonies are blackish when alive.

(9) Botrylloides violaceus OKa Eight blackish colonies and a single pinkish colony. In formalin, the test is milky white and translucent to transparent, while zooids are pale purplish gray (pinkish colony) to purplish brown and usually up to $1.75 \mathrm{~mm}$ in length. Colonies are usually $2-3 \mathrm{~mm}$ thick, but to $5-6 \mathrm{~mm}$ in folded portions. Eleven to 13 stigmatal rows (usually one more row on the left side). Eleven to 12 plications on the stomach, including typhlosole. Up to 20 , but generally up to 15 , testicular follicles; the ovary is situated on the posterior side or at the dorsoposterior edge of the testis. Some colonies are fully matured and contain large $(1.5 \mathrm{~mm}$ long) larvae within; about 30 elongate ampullae are included in each larva.

(10) Styela partita (Stimpson) Seven specimens, 16-17 mm in length, coloured vermilion when alive. Preserved specimens are yellowish brown to brownish. The 
stomach occupies nearly the whole length of the ventral branch of the intestinal loop. The axis of the second intestinal loop passes through the cardiac portion of the stomach.

(11) Styela clava Herdman Small, $23 \mathrm{~mm}$ and $25 \mathrm{~mm}$ long brownish individuals, respectively with $7 \mathrm{~mm}$ and $10 \mathrm{~mm}$ long peduncle. The descending branch of the intestinal loop is longer than a half of the ascending branch. The stomach is longer than a half of the descending branch. Respectively with 4 and 8 gonads on the right side.

Acknowledgement: At closing these notes, I want to express here my hearty thanks to Dr. T. KiтAmi for his kindness in giving me this chance to examine the present specimens. 